\title{
Polymerase chain reaction amplified HTLV-I, HIV -1 and HIV-2 DNA fragments in subjects with mixed retroviral infections
}

\author{
V. KOLESNITCHENKO, G. AGIUS*, J. F. ZAGURY, K. LAAROUBI, A. ACHOUR, M. CASTETS* \\ and D. ZAGURY
}

Laboratoire de Physiologie Cellulaire, Université Pierre et Marie Curie, 4 Place Jussieu, 75230 Paris and

* Laboratoire de Microbiologie B, CHU La Milétrie, BP577, 86021 Poitiers, France

\begin{abstract}
Summary. Serum and peripheral blood mononuclear cells from eight patients from the Ivory Coast with positive screening test results for retroviral infections were studied by serology (ELISA, Western blot (WB), synthetic peptide test), cell co-culture, and polymerase chain reaction (PCR). Two HIV-2 infections with indeterminate interpretation on HIV-1 WB were detected, two were clear dual HIV-1/HIV-2 infections, three were ambiguous mixed HIV1/HIV-2 infections, and one was a triple retroviral infection by HTLV-I, HIV-1 and HIV-2. Four slow/low HIV-1 strains were isolated at the expense of HTLV-I and HIV-2 strains. The ELISA tests were found to be very sensitive. Indeterminate WB interpretations were frequent (HTLV-I, four; HIV-1, three; HIV-2, two). PCR provided clear evidence of multiple retroviral infections in three cases and enabled interpretation of indeterminate WB samples in three cases. One sample presented a puzzling pattern with positive PCR results for HIV-1 and HIV-2 associated with negative or indeterminate serological results. Thus, our data emphasise the need to analyse serological as well as virological markers to gain better insight on mixed retroviral infections, especially in endemic areas such as West Africa.
\end{abstract}

\section{Introduction}

The human T-cell leukaemia virus type I (HTLV-I) was the first human retrovirus discovered. HTLV-I, first isolated from a patient thought to have mycosis fungoides, ${ }^{1}$ has been strongly associated with a rare form of lymphoma called adult T-cell leukaemia/ lymphoma (ATL). ${ }^{2}$ The human immunodeficiency viruses, type 1 (HIV-1) and type 2 (HIV-2), are causative agents of the acquired immunodeficiency syndrome (AIDS). ${ }^{3,4}$

Geographic distributions of these three major human retroviruses are different. HTLV-I is endemic in Southwestern Japan, the Caribbean basin and subSaharan Africa. ${ }^{5}$ HIV-1 appears as a worldwide epidemic, whereas HIV-2 has been mainly reported in West Africa. ${ }^{6}$ Numerous seroprevalence surveys have reported mixed retroviral infections. ${ }^{7,8}$ However, serological techniques did not always allow clear discrimination between the multiple infections. These patterns are especially frequent in West Africa. ${ }^{8}$

In this report, data obtained with serology, cell coculture and polymerase chain reaction (PCR) on samples from Ivory Coast subjects showing positive screening test results for co-infection are examined.

\section{Materials and methods}

\section{Samples}

Serum and peripheral blood mononuclear cells (PBMCs) were collected in 1988 from eight subjects (nos. 1-8) residing in Abidjan, Ivory Coast. None of these (four males and four females) was diagnosed as having AIDS or ATL. Three subjects presented with sickle-cell anaemia and one with an infiltration of the upper lip, stains on the sole of the foot and palm of the hand. The others were healthy individuals.

\section{ELISA}

Sera were screened by ELISA for antibodies to HTLV-I/II (HTLV-I Elisa; DuPont/Biotech, Wilmington, DE, USA), HIV-1 (HIV-1/HIV-2 EIA recombinant; Abbott, North Chicago, IL, USA) and HIV-2 (Elavia Ac-Ab-Ak II; Diagnostics Pasteur, Marnes-la-Coquette, France). The procedures and evaluations were done according to the manufacturers' instructions.

\section{Western blot $(W B)$}

All sera were examined by WB testing (DuPont/ 
Biotech and Cambridge Biotech for HTLV-I/II; DuPont/Biotech for HIV-1; Diagnostics Pasteur for HIV-2). The WB assays were performed according to the manufacturers' instructions.

In WB HTLV-I strips from Cambridge Biotech, native viral polypeptides were combined with a purified recombinant transmembrane envelope protein (p21) to increase the sensitivity for $e n v$ antibodies and the specificity to encompass HTLV-II reactive antibodies. ${ }^{9}$ The criterion for a serum to be considered HTLV-I/II positive by WB analysis was the presence of gp61 or gp46 or p21 reactivity with, at least, p19 or p24 reactivity. Sera without any WB reactivity (i.e., blank) were considered to be negative. All other WB profiles were labelled as indeterminate.

Samples were considered to be positive for antibodies to HIV-1 or HIV-2 if they reacted with at least two envelope proteins and one of the gag proteins.

\section{Synthetic peptide test}

The Pepti-LAV 1-2 test (Diagnostics Pasteur) was used to discriminate serologically between HIV-1 and HIV-2 infection. This test is based on the use of two synthetic peptides. ${ }^{10}$ HIV-1 peptide imitates an immunodominant epitope of the gp41 envelope glycoprotein. HIV-2 peptide imitates an epitope of the gp36 envelope glycoprotein. The assay was performed according to the manufacturer's instructions. The following criteria were used for reading band intensities: the control band (IgG control) corresponded to a response intensity arbitrarily labelled as $(++)$; each band was scored by eye by comparison with the intensity obtained on the control band; any positive band with an intensity equal to or greater than or lower than that of the control band was labelled as $(++)$ or $(+)$, respectively; any minor distinct staining was marked as $(+/-)$. Absence of reactivity corresponded to a negative response.

\section{Cell co-culture}

Peripheral blood mononuclear cells (PBMCs) from patients and healthy seronegative subjects were collected on a Ficoll gradient from 30-ml samples of heparinised blood. PBMCs from healthy donors were stimulated by exposure to phytohaemagglutinin (PHA; Difco) $0.1 \%$ for 3 days in RPMI 1640 medium containing fetal calf serum $10 \%$, penicillin $100 \mathrm{U} / \mathrm{ml}$ and streptomycin $100 \mu \mathrm{g} / \mathrm{ml}$. Then, $5 \times 10^{6}$ PHAstimulated PBMCs were added to $10^{7}$ PBMCs from a patient and cultured in RPMI 1640 medium with fetal calf serum $10 \%$, antibiotics and interleukin 2 (Transgene, USA) $250 \mathrm{U} / \mathrm{ml}$. Tissue-culture flasks were incubated at $37^{\circ} \mathrm{C}$ in air with $\mathrm{CO}_{2} 5 \%$. At twice weekly intervals, half of the cells were split, enumerated with Trypan blue, and checked for reverse transcriptase (RT) activity. An equal volume of medium was added to the rest of the cells to continue the culture and a further inoculum of PHA-stimulated PBMCs was added once a week.

HTLV-I, HIV-1 and HIV-2 antigens were detected by indirect immunofluorescence assay with serum from infected patients.

\section{DNA preparation}

The PBMCs obtained by Ficoll separation were washed twice in phosphate-buffered saline (PBS). The final pellet was suspended in lysis buffer containing $10 \mathrm{~mm}$ Tris- $\mathrm{HCl}, \mathrm{pH} 8.0 ; 10 \mathrm{~mm}$ EDTA, pH 8.0; $10 \mathrm{mM} \mathrm{NaCl}$, SDS $0.5 \%$ and proteinase $\mathrm{K}$ (Boehringer, Mannheim, Germany) $250 \mu \mathrm{g} / \mathrm{ml}$ and incubated overnight at $37^{\circ} \mathrm{C}$. After phenol-chloroform extraction, the DNA was precipitated with 0.1 volume of $3 \mathrm{M}$ sodium acetate and 2 volumes of absolute ethanol at $-80^{\circ} \mathrm{C}$ for at least $1 \mathrm{~h}$. The DNA was pelleted by centrifugation at $2000 \mathrm{~g}$ for $30 \mathrm{~min}$, washed twice with ethanol $70 \%$ and dried under vacuum.

\section{PCR}

The PCR was performed as described previously. ${ }^{11}$ Two pairs of oligonucleotides in the gag and pol regions of the HIV-1 genome, two pairs in the pol and $e n v$ regions of the HIV-2 genome, and one pair in the gag region of the HTLV-I genome were selected as primers. The characteristics of the primers used (The Midland Certified Reagent Company, USA) are shown in table I.

The PCR mixture (100 $\mu$ l) contained PBMC DNA $1 \mu \mathrm{g}, 1 \mu \mathrm{M}$ each of primers, $200 \mu \mathrm{M}$ each of four dNTPs, $10 \mathrm{~mm}$ Tris- $\mathrm{HCl}, \mathrm{pH} 8.3,50 \mathrm{mM} \mathrm{KCl}, 1.5 \mathrm{mM} \mathrm{MgCl}_{2}$, gelatin $0.001 \% \mathrm{w} / \mathrm{v}$, and AmpliTaq polymerase (Perkin Elmer Cetus, Norwalk, CT, USA) 2.5 units. The amplification was performed with a DNA thermal cycler (Perkin Elmer Cetus). The PCR procedure involved an initial denaturation step at $94^{\circ} \mathrm{C}$ for $10 \mathrm{~min}$ followed by 25 cycles of $2 \mathrm{~min}$ at $53^{\circ} \mathrm{C}$ for annealing, $3 \mathrm{~min}$ at $72^{\circ} \mathrm{C}$ for extension, and $1 \mathrm{~min}$ at $94^{\circ} \mathrm{C}$ for denaturation, and a final cycle with the extension time increased to $10 \mathrm{~min}$.

\section{Analysis of PCR products}

The PCR product $(10 \mu \mathrm{l})$ was resolved by electrophoresis on agarose $1.8 \%$ gel. After denaturing and neutralising steps, the gel was blotted on to a nitrocellulose membrane (Schleicher and Schuell, Keene, $\mathrm{NH}$, USA). Hybridisation was performed with a ${ }^{32} \mathrm{P}-$ labelled probe and an oligolabelling kit (Pharmacia, Uppsala, Sweden). The HTLV-I probe was an SstI-SstI fragment from the $p M T-2$ clone (Biotech); the HIV-1 probe was an SstI-SstI fragment from the $B H-10$ clone; ${ }^{13}$ and the HIV-2 probe was an StuI-StuI fragment from the HIV-2 NIH-DZ clone ${ }^{14}$ Hybridisation was performed in the presence of $2 \times \mathrm{SSC}$, dextran sulphate $10 \%$, SDS $1 \%$, Denhart solution 
Table 1. Primers for DNA amplification by PCR

\begin{tabular}{|c|c|c|c|c|}
\hline $\begin{array}{l}\text { Primer } \\
\text { designation }\end{array}$ & \multicolumn{3}{|c|}{ Sequence $\left(5^{\prime}-3^{\prime}\right)$} & Location* \\
\hline \multicolumn{5}{|l|}{ HTLV-1 } \\
\hline & 1 & CGACCGCCCCGGGGGCTGGCCGCT & $\operatorname{gag}$ & $863-886$ \\
\hline & 2 & TATCCTTTTGGGAGTAGGCTGGC & gag & $1050-1028$ \\
\hline \multicolumn{5}{|c|}{ 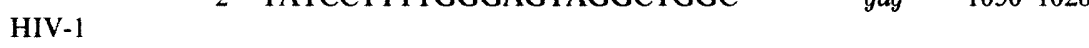 } \\
\hline & 3 & АТАAТССАССТАТСССAGTAGGAGAAAT & gag & $1543-1570$ \\
\hline & 4 & TTTGGTCCTTGTCTTATGTCCAGAATGC & gag & $1657-1630$ \\
\hline & 5 & TGGGAAGTTCAATTAGGAATACCAC & pol & $2810-2834$ \\
\hline & 6 & CCTACATACAAATCATCCATGTATT & pol & $3117-3093$ \\
\hline 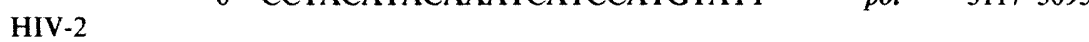 & 7 & CCATACCACTACATGAGGAC & pol & $2722-2741$ \\
\hline & 8 & GCAACTTCCATTTAGTTGGC & pol & $3096-3077$ \\
\hline & 9 & TTGGCTTTAATGGCACTA & env & $6914-6931$ \\
\hline & 10 & AGGAACCAAGTCATGTTGCA & env & $7322-7303$ \\
\hline
\end{tabular}

*The locations were determined from the sequence published by Myers et al. ${ }^{12}$

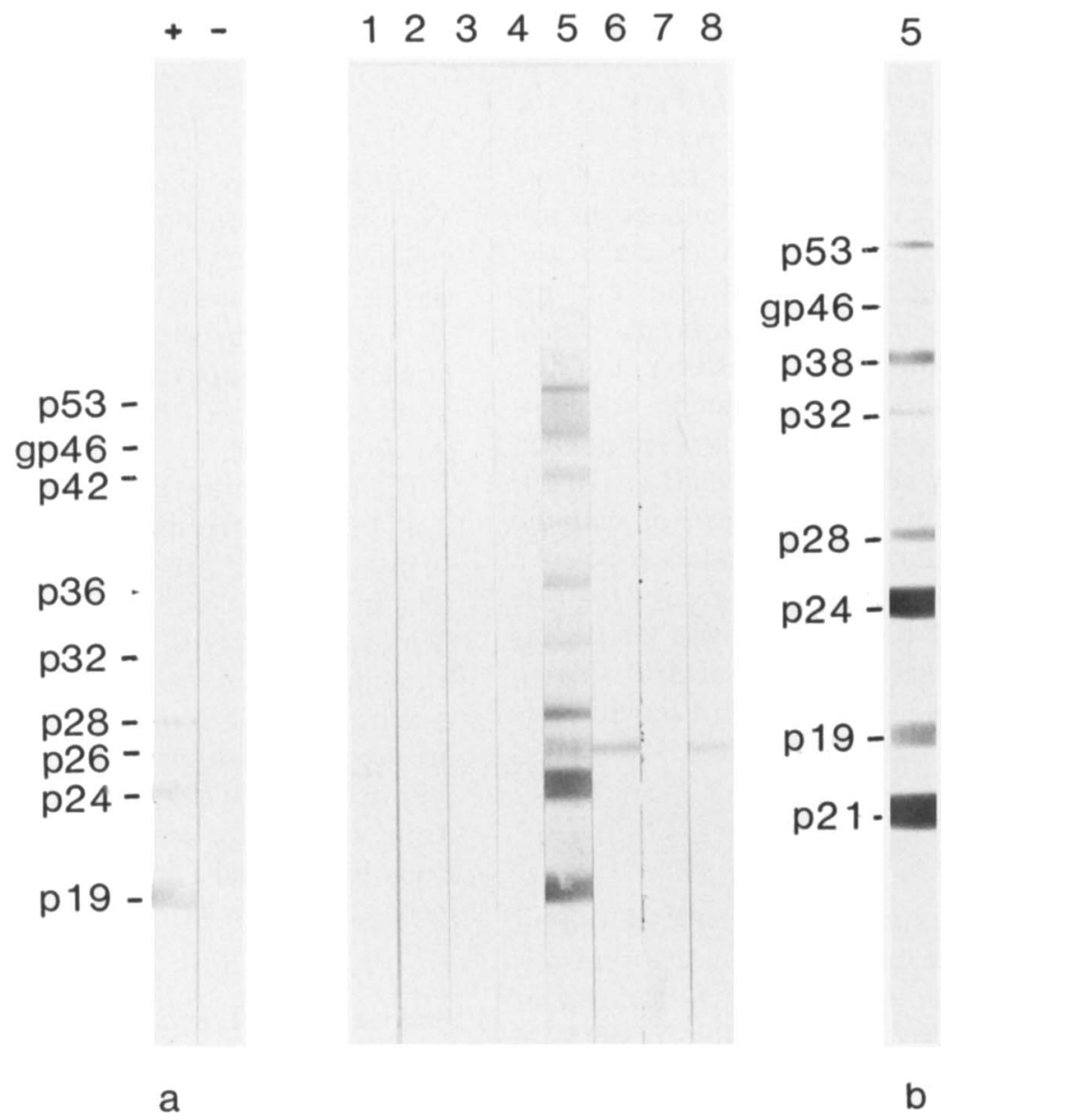

Fig. 1. a, HTLV-I WB patterns obtained with DuPont/Biotech assay for sera nos. 1-8. b, HTLV-I WB pattern obtained with Cambridge Biotech assay for serum no. 5 ; this test includes the recombinant 221 env protein.

$5 \%, 20 \mathrm{mM} \mathrm{Na}_{2} \mathrm{HPO}_{4}$, $\mathrm{pH} \mathrm{6.5}$, and salmon sperm DNA $100 \mu \mathrm{g} / \mathrm{ml}$ at $45^{\circ} \mathrm{C}$ overnight. Then, the filters were washed in $2 \times \operatorname{SSC}$, SDS $0.1 \%$ for $2 \mathrm{~h}$ at $45^{\circ} \mathrm{C}$, and exposed to Kodak XAR film overnight. The film was developed and the filters were washed a second time if necessary at $55^{\circ} \mathrm{C}$ with the same buffer and reexposed to Kodak film.

\section{Results}

\section{Immunoserology}

HIV ELISA screening tests showed very strong positive results $(O D>1.000$ with a cut-off at 0.180 for HIV-1 and 0.300 for HIV-2) for all sera, except no. 4 


\section{$+-12345678$}

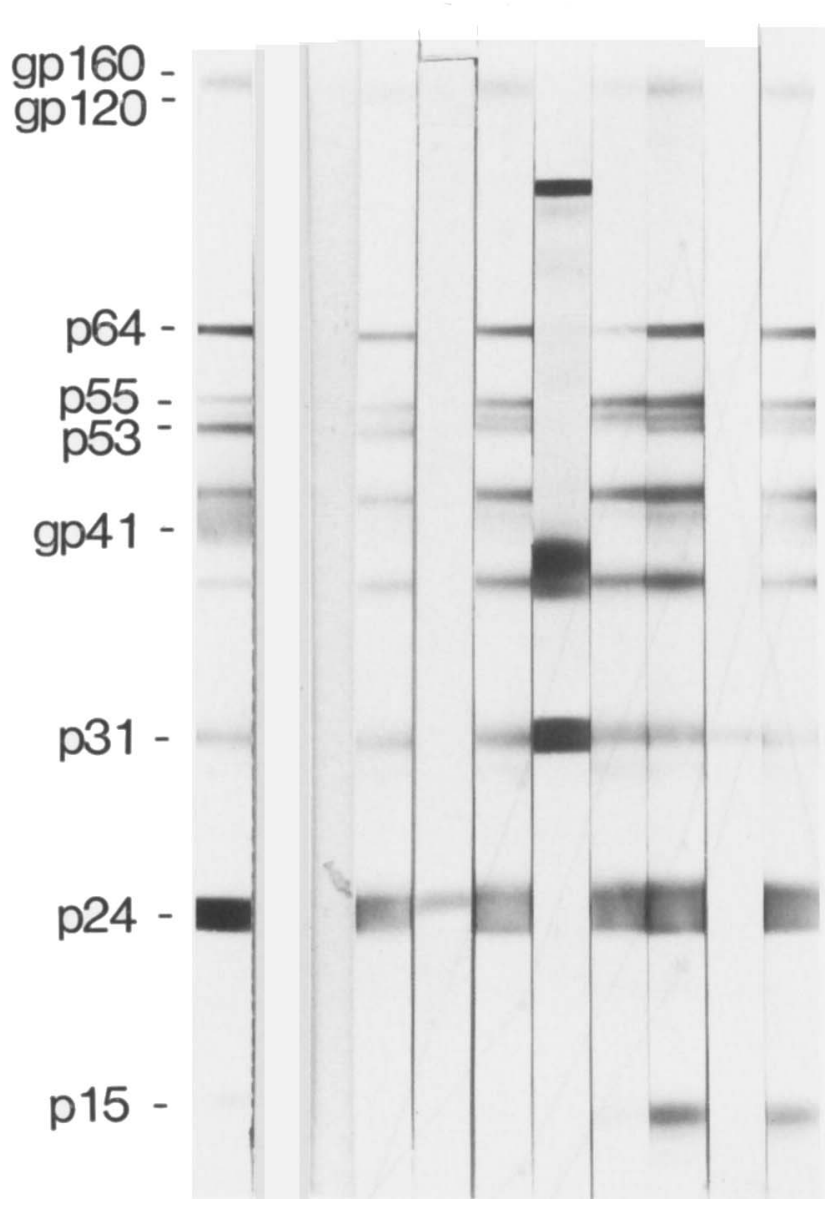

Fig. 2. HIV-1 WB patterns obtained for sera nos. 1-8.

for HIV-1 and no. 7 for HIV-2. Only serum no. 5 was positive in the HTLV-I ELISA (OD 1.800 with a cutoff at 0.741 ).

The result with serum no. 5 was confirmed by strong reactions in many bands in the HTLV-I WB (fig. 1). However, five samples showed indeterminate WB patterns: no. 1 with a p24 band alone; no. 4 with p32 and p53 bands and another reactivity located higher than the p53 band; nos. 6 and 8 with the p 26 band alone. Serum no. 5 was reblotted with a strip that included the recombinant $\mathrm{p} 21$ env protein; the intensity of the p24 band was greater than that of the p19 band.

Sera nos. 1, 3, 5, 6 and 8 had complete HIV-1 WB profiles except that $\mathrm{p} 15$ reactivity was missing with nos. 1 and 3 (fig. 2). Three samples showed indeterminate WB profiles. Among these, an unusual pattern was observed with sample no. 4 , and samples nos. 2 and 7 had single bands only at p24 and p31, respectively.

Sera nos. 1-5 presented HIV-2 patterns compatible with an HIV-2 infection (fig. 3). All these samples had a characteristic gp105 reactivity corresponding to an antigen encoded by the env gene. Intensity was weaker with sera nos. 3 and 4 . Indeterminate patterns were observed with serum no. 6 (p26, p56 and p68 bands)

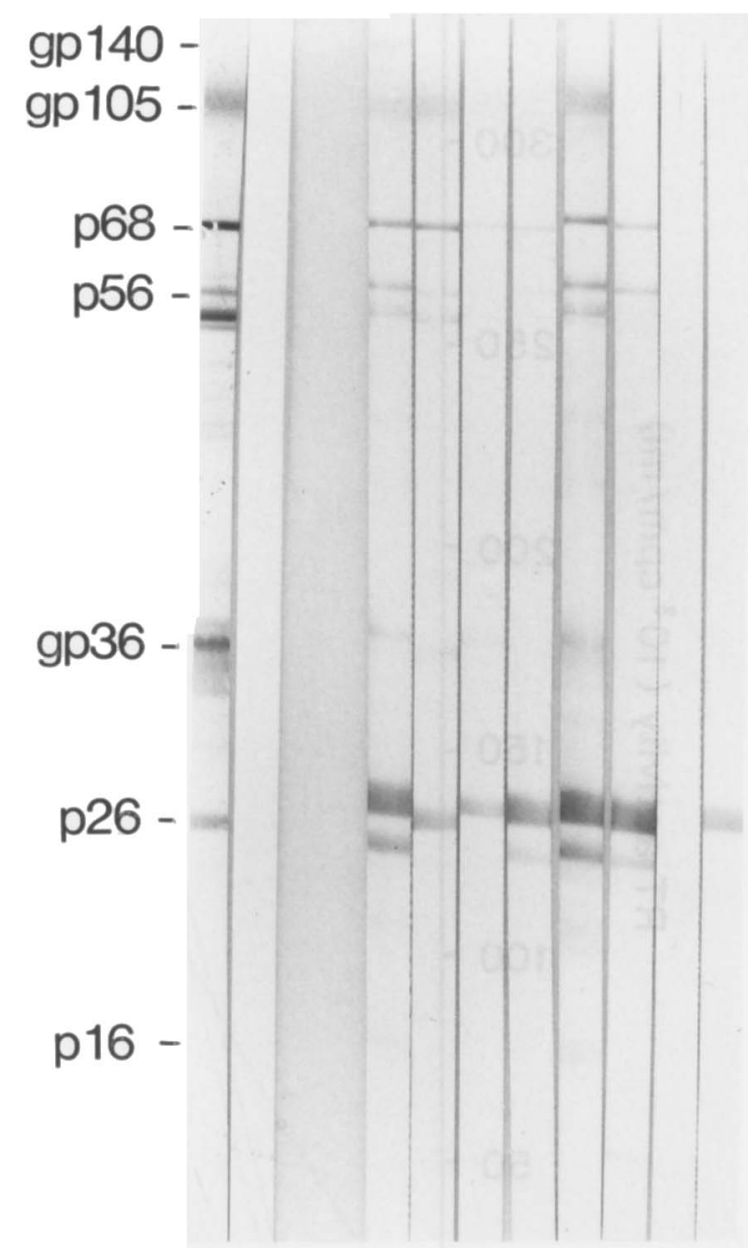

Fig. 3. HIV-2 WB patterns obtained for sera nos. 1-8.

\section{$\begin{array}{llllll}1 & 3 & 4 & 5 & 6 & 7\end{array}$}

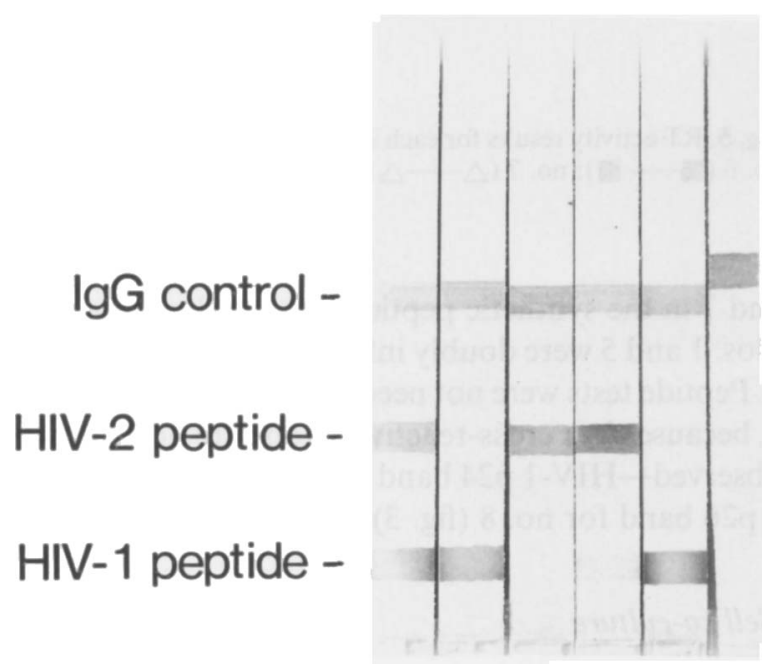

Fig. 4. Results of the synthetic peptide test for HIV-1/HIV-2 antibody differentiation for samples nos. $1,3,4,5,6$ and 7 .

and no. 8 (p26 band alone). Sample no. 7 gave a completely blank result.

The results obtained with samples nos. 1, 3, 4, 5, 6 


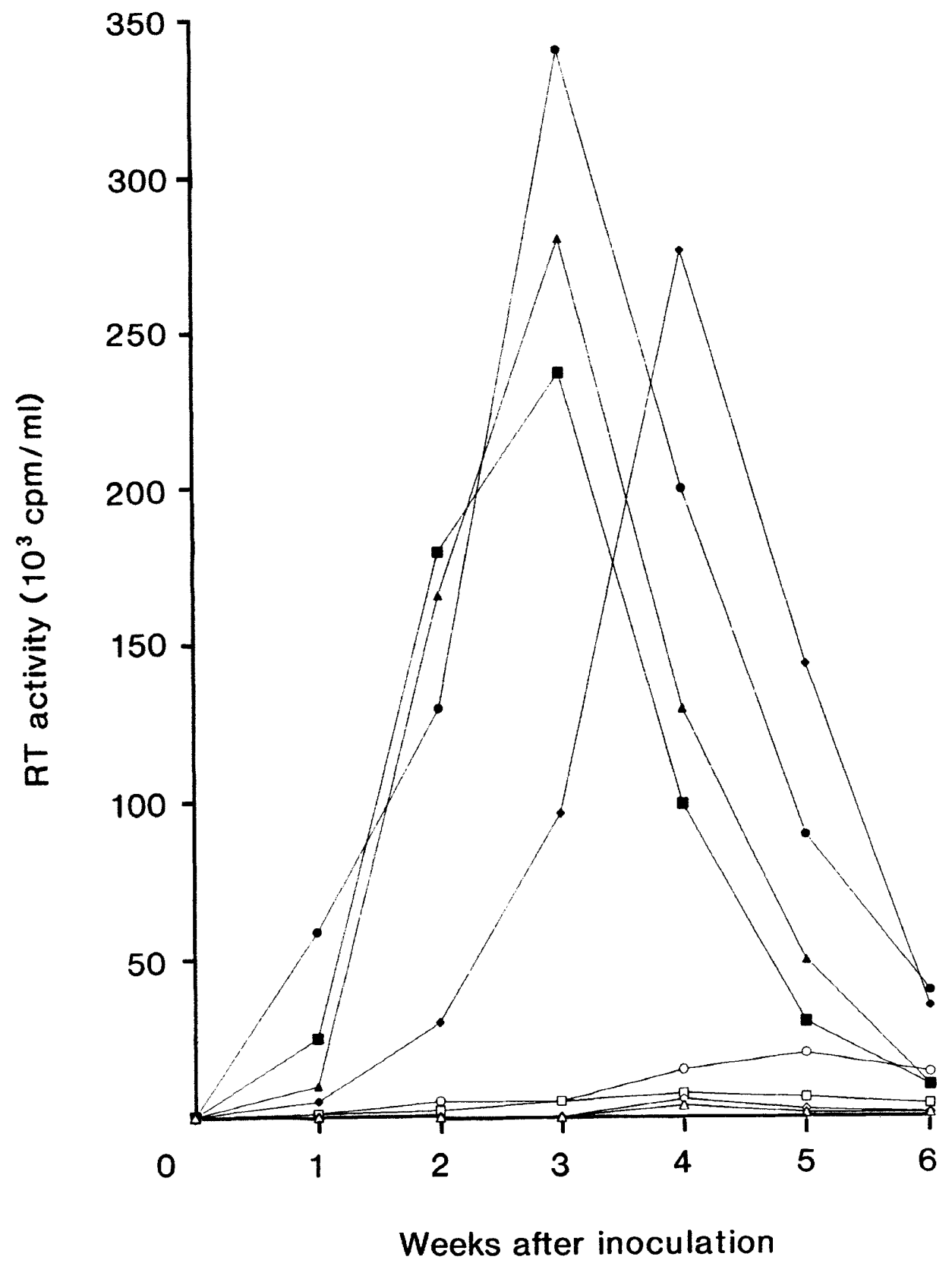

Fig. 5. RT activity results for each PBMC sample: no. $1(\bigcirc-\bigcirc)$; no. $2(\square-\square)$; no. 3 no. $6(\mathbf{\square})$; no. $7(\triangle-\triangle)$; and no. 8

and 7 in the synthetic peptide test are shown in fig. 4 . Nos. 1 and 5 were doubly infected by HIV-1 and HIV2. Peptide tests were not needed for samples nos. 2 and 8 , because clear cross-reactivities on core proteins were observed-HIV-1 p24 band for no. 2 (fig. 2) and HIV2 p26 band for no. 8 (fig. 3 ).

\section{Cell co-culture}

An RT activity was obtained with four $(50 \%)$ samples (fig. 5). The peak of RT activity was reached after 3 weeks of co-culture for cells from subjects nos. 5,6 and 8 , and 4 weeks for no. 3. The highest peak $\left(340 \times 10^{3} \mathrm{cpm} / \mathrm{ml}\right)$ was observed with sample no. 8 . However, weak RT activities of $10^{3}-20 \times$ $10^{3} \mathrm{cpm} / \mathrm{ml}$, were detected with other samples. Only
HIV-1 reactivities were detected by the indirect immunofluorescence assay.

\section{PCR studies}

DNA extracted from PBMCs from each patient was amplified by PCR with all sets of primers. All the amplified DNA fragments were subjected to Southern blot analysis.

The amplified HTLV-I DNA fragment from sample no. 5 was the only one to yield a 188 -bp band visible on an ethidium bromide-stained gel under UV light, as well as on Southern blot (fig. 6). Six (75\%) DNA samples were amplified with at least one of the two HIV-1 pairs of primers; nos. 2 and 4 gave completely negative results (fig. 7). All DNA preparations gave 


\section{$\begin{array}{lllllllllll}1 & 2 & 3 & 4 & 5 & 6 & 7 & 8 & - & +\end{array}$}

$188 \mathrm{bp}-$

Fig. 6. Southern blot analysis of amplified HTLV-I DNA sequence obtained with primers 1,2 in the gag region for the eight samples.

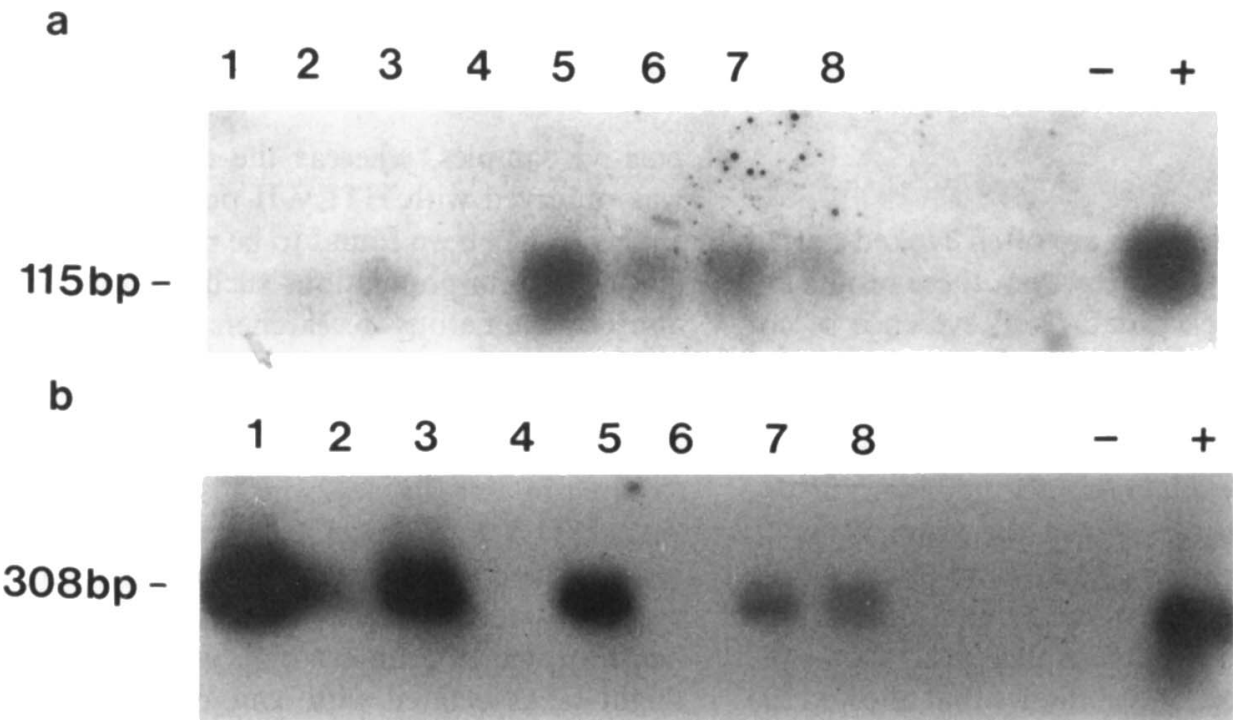

Fig. 7. Southern blot analysis of amplified HIV-1 DNA sequence for the eight samples obtained with (a) primers 3,4 in the gag region, and (b) primers 5,6 in the pol region.

a

$\begin{array}{lllllll}1 & 2 & 3 & 4 & 5 & 6 & 7\end{array}$

8
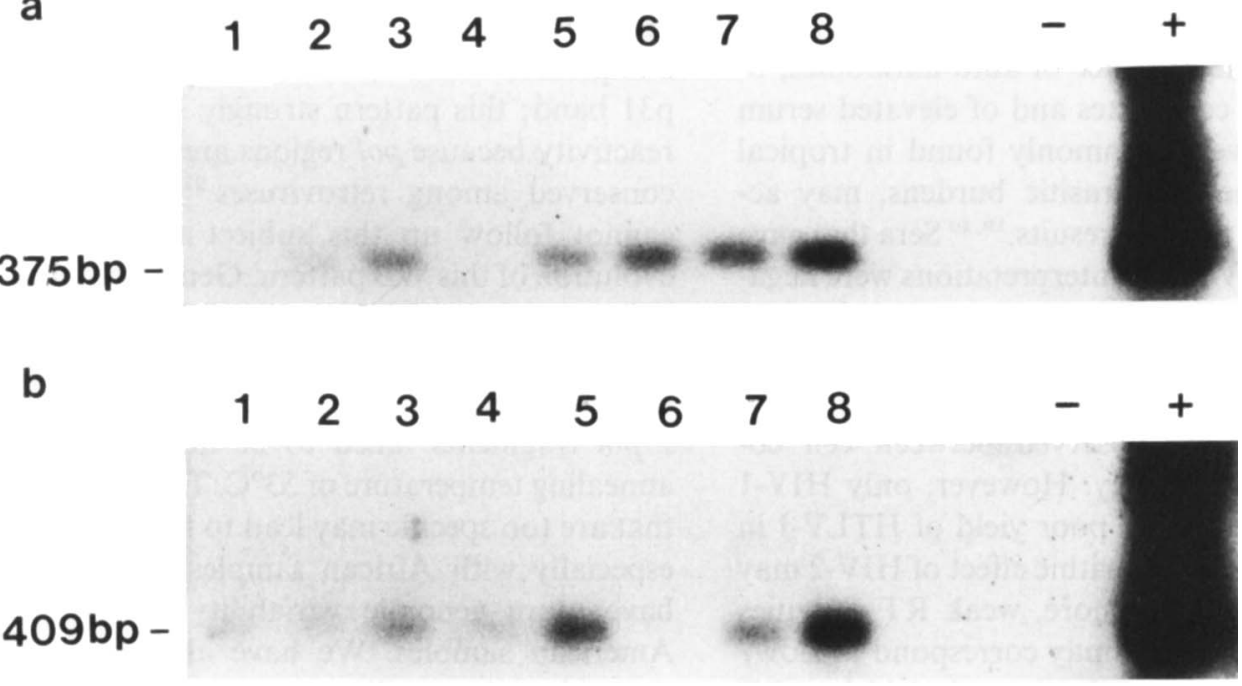

Fig. 8. Southern blot analysis of amplified HIV-2 DNA sequence for eight samples obtained with (a) primers 7, 8 in the pol region, and (b) primers 9,10 in the env region.

positive results with at least one pair of HIV-2 primers (fig. 8). Sample no. 6 showed a positive result with a 375-bp spot amplified in the HIV-2 pol region whereas the Southern blot corresponding to the env amplified fragment was negative.

Overall results are summarised in table II. 
Table II. HTLV-I, HIV-1 and HIV-2 infections characterised by culture, serological and PCR techniques on samples from eight patients

\begin{tabular}{|c|c|c|c|c|c|c|c|c|c|c|c|c|c|}
\hline \multirow{2}{*}{$\begin{array}{c}\text { Patient } \\
\text { no. }\end{array}$} & \multicolumn{3}{|c|}{ HTLV-I } & \multicolumn{3}{|c|}{ HIV-1 } & \multicolumn{3}{|c|}{ HIV-2 } & \multicolumn{2}{|c|}{$\begin{array}{l}\text { Synthetic } \\
\text { peptide } \\
\text { test }\end{array}$} & \multirow{2}{*}{$\begin{array}{l}\text { Culture } \\
\text { (RT) }\end{array}$} & \multirow{2}{*}{$\begin{array}{l}\text { Conclusions } \\
\text { on retroviral } \\
\text { infection }\end{array}$} \\
\hline & ELISA & WB & PCR & ELISA & WB & PCR & ELISA & WB & PCR & 1 & 2 & & \\
\hline 1 & - & $\mathrm{i}$ & - & + & + & + & + & + & + & ++ & ++ & - & Mixed HIV-1/2 \\
\hline 2 & - & - & - & + & $\mathrm{i}$ & - & + & + & + & ND & ND & - & HIV-2 only \\
\hline 3 & - & - & - & + & + & + & + & + & + & ++ & - & + & Mixed HIV-1/2 \\
\hline 4 & - & $\mathrm{i}$ & - & - & $\mathrm{i}$ & - & + & + & + & - & ++ & - & HIV-2 only \\
\hline 5 & + & + & + & + & + & + & + & + & + & + & ++ & + & HTLV-I, HIV-1/2 \\
\hline 6 & - & $\mathrm{i}$ & - & + & + & + & + & $\mathrm{i}$ & + & ++ & - & + & HIV-1, HIV-2? \\
\hline 7 & - & - & - & + & $\mathrm{i}$ & + & - & - & + & - & - & - & HIV-1, HIV-2? \\
\hline 8 & - & $\mathrm{i}$ & - & + & + & + & + & $\mathrm{i}$ & + & ND & ND & + & HIV-1, HIV-2? \\
\hline
\end{tabular}

i, WB with an indeterminate interpretation; ND, not done.

\section{Discussion}

Mixed retroviral infections are often evoked during epidemiological surveys. ${ }^{7,8}$ However, these results are based only on serological data, and evidence of coinfection is rarely sought by culture ${ }^{15,16}$ or molecular analysis. ${ }^{17}$ Our samples from Ivorian patients had a high probability of showing such serological patterns. Several reasons may explain this phenomenon: firstly, the rate of AIDS progression in the Ivory Coast ${ }^{18}$; secondly, its geographical situation in West Africa where HIV-2 is more prevalent ${ }^{18}$ and thirdly, the presence of HTLV-I infection in this area. ${ }^{8}$

In this study, a panel of techniques that allowed the precise diagnosis of these multiple infections was used. Investigative strategies usually include a highly sensitive ELISA screening test; the three ELISAs were found to be very sensitive. However, the HIV ELISAs showed non-specific reactions. This observation has been widely reported, ${ }^{19}$ especially with sera from African subjects. The presence of auto-antibodies, of circulating immune complexes and of elevated serum immunoglobulin levels, commonly found in tropical populations with heavy parasitic burdens, may account for these false positive results. ${ }^{19,20}$ Sera that gave indeterminate HTLV-I WB interpretations were negative by ELISA.

The rate of HIV-positive cultures in confirmed seropositive persons varies from 10 to $95 \% .{ }^{21}$ No discrepant results were observed between cell coculture and immunoserology. However, only HIV-1 isolates were obtained. The poor yield of HTLV-I in culture and the weaker cytopathic effect of HIV-2 may explain this result. Furthermore, weak RT activities detected, with four samples may correspond to slow/ low HIV strains that grow slowly and yield low RT activity. These poorly replicating strains are often obtained from individuals with no or mild disease. ${ }^{22}$

Immunoblot and PCR results for HTLV-I showed one clearly seropositive serum (no. 5). Wiktor et al. ${ }^{9}$ found that the intensity of the p24 band was usually greater than that of the p19 band in most HTLV-I positive samples, whereas the opposite WB pattern was observed with HTLV-II positive samples. Since HTLV-II has been found to be more highly prevalent among certain populations such as intravenous drug abusers, numerous researchers have attempted to establish reliable tests to differentiate between HTLVI and HTLV-II infections. ${ }^{9}{ }^{23}$ Four sera produced an indeterminate interpretation on WB with reactivities to core proteins (fig. 1a), which is commonly observed with HTLV-I infection. ${ }^{24}$ These bands might correspond to cross-reactions with other retroviruses, especially simian retroviruses. ${ }^{25}$ Another non-specific band located at a higher mol. wt than the $\mathrm{p} 53$ band might be associated with contamination of the viral antigen preparation by HLA or HLA-like antigens from the producing cell line. ${ }^{26}$

Two patients were HIV-2 positive (nos. 2 and 4 ) with an indeterminate HIV-1 WB. The presence of a p24 band alone (no. 2) may correspond to antigenic crossreactivity between HIV-1 and HIV-2 gag proteins. Sample no. 4 showed three bands, one of which was a p31 band; this pattern strongly suggests a retroviral reactivity because pol regions are known to be highly conserved among retroviruses. ${ }^{27}$ Unfortunately, we cannot follow up this subject to see if there was evolution of this WB pattern. Generally, these unusual WB patterns rarely change on follow-up testing. ${ }^{21}$

Two mixed HIV-1/HIV-2 infections (nos. 1 and 3) were detected. For sample no. 1, HIV-1 gag and HIV2 pol fragments failed to be amplified at a primer annealing temperature of $53^{\circ} \mathrm{C}$. Thus, PCR conditions that are too specific may lead to false negative results, especially with African samples that are known to have more genomic variability than European or American samples. We have already demonstrated that a lower annealing temperature allows a certain degree of sequence mismatch. ${ }^{11}$ However, this protocol remains difficult for diagnostic purposes. This emphasises the necessity to use multiple primer pairs located in different regions of the HIV genome. ${ }^{27}$ For sample no. 3, only the synthetic peptide test (fig. 4) was unable to show an HIV-2 positive infection. This type of 
pattern was observed by Simon et al. ${ }^{28}$ who suggest titration of antibody against specific peptides and comparison of titres for diagnosis of double infection.

We detected three ambiguous mixed HIV-1/HIV-2 infections (nos. 6, 7 and 8). However, nos. 6 and 8 showed a clear-cut HIV-1 positivity. The discrepancies observed between HIV-2 WB and PCR results did not resolve this problem. The indeterminate HIV-2 WB interpretations are probably associated with false positive PCR results. ${ }^{27}$ Homologies between human retroviruses might explain this finding. ${ }^{27}$ Moreover, Böttiger et $a l^{29}$ have demonstrated envelope protein cross-reactivity between HIV-1 and HIV-2. For subject no. 7, only the PCR results demonstrated a mixed HIV-1/HIV-2 infection. In this case, other tests such

\section{References}

1. Poiesz BJ, Ruscetti FW, Gazdar AF, Bunn PA, Minna JD, Gallo RC. Detection and isolation of type $C$ retrovirus particles from fresh and cultured lymphocytes of a patient with cutaneous T-cell lymphoma. Proc Natl Acad Sci USA 1980; $77: 7415-7419$.

2. Hinuma $Y$, Gotoh $Y$, Sugamura $\mathrm{K}$ et al. A retrovirus associated with human adult T-cell leukemia: in vitro activation. Jpn J Cancer Res 1982; 73: 341-344.

3. Gallo RC, Salahuddin SZ, Popovic M et al. Frequent detection and isolation of cytopathic retroviruses (HTLV-III) from patients with AIDS and at risk for AIDS. Science 1984; 224: $500-503$.

4. Clavel F, Guétard D, Brun-Vézinet F et al. Isolation of a new human retrovirus from West African patients with AIDS. Science 1986; 233: 343-346.

5. Blattner WA, Blayney DW, Robert-Guroff M et al. Epidemiology of human T-cell leukemia/lymphoma virus. J Infect Dis $1983 ; 147$ : 406-416.

6. Horsburgh CR, Holmberg S. The global distribution of human immunodeficiency virus type 2 (HIV-2) infection. Transfusion 1988; 28: 192-195.

7. Cardoso EA, Robert-Guroff M, Franchini $G$ et al. Seroprevalence of HTLV-I in Portugal and evidence of double retrovirus infection of a healthy donor. Int J Cancer 1989; 43: 195-200.

8. Verdier M, Denis F, Sangaré A et al. Prevalence of antibody to human T cell leukemia virus type I (HTLV-I) in populations of Ivory Coast, West Africa. J Infect Dis 1989; 160: 363-370.

9. Wiktor SZ, Alexander SS, Shaw GM et al. Distinguishing between HTLV-I and HTLV-II by Western blot. Lancet $1990 ; 335: 1533$.

10. Gnann JW, McCormick JB, Mitchell S, Nelson JA, Oldstone MBA. Synthetic peptide immunoassay distinguishes HIV type 1 and HIV type 2 infections. Science 1987; 237: 1346-1349.

11. Agius G, Kolesnitchenko V, Snart R, Zagury JF, Laaroubi K, Zagury $\mathrm{D}$. Variable stringency hybridization of polymerase chain reaction amplified HIV-1 DNA fragments. $J$ Virol Methods 1990; 30: 141-150.

12. Myers G, Korber B, Berzofsky JA, Smith RS, Pavlakis GN (eds). Human retroviruses and AIDS: a compilation and analysis of nucleic acid and amino acid sequences. Los Alamos, National Laboratory, Theoretical Biology and Biophysics Group T-10, 1991.

13. Hahn BH, Shaw GM, Arya SK, Popovic M, Gallo RC, WongStaal F. Molecular cloning and characterization of the HTLV-III virus associated with AIDS. Nature 1984; 312: 166-169.

14. Zagury JF, Franchini G, Reitz M et al. Genetic variability as radio-immunoprecipitation assay or sequence analysis of PCR amplified DNA fragments are needed.

A triple retroviral infection (no. 5) was clearly demonstrated with each of the techniques. Bartholomew et al ${ }^{30}$ suggested that multiple-infected subjects may be at greater risk of developing AIDS. Thus, PCR analysis could provide new information in areas where the prevalence of HTLV-I/II, HIV-1 and HIV-2 is high. ${ }^{8,18}$

Finally, these data obtained with "difficult samples" point to the need to develop and compare other virological tests for the detection of mixed retroviral infections. PCR could be a valuable additional technique for characterising these multiple retroviral infections. between isolates of human immunodeficiency virus (HIV) type 2 is comparable to the variability among HIV type I. Proc Natl Acad Sci USA 1988; 85: 5941-5945.

15. Kanner SB, Parks ES, Scott GB, Parks WP. Simultaneous infections with human $T$ cell leukemia virus type $I$ and the human immunodeficiency virus. J Infect Dis 1987; 155: 617-625.

16. Getchell JP, Heath JL, Hicks DR, Sporborg C, Mann JM, McCormick JB. Detection of human T cell leukemia virus type I and human immunodeficiency virus in cultured lymphocytes of a Zairian man with AIDS. $J$ Infect Dis 1987; 155: 612-616.

17. Rayfield M, De Cock K, Heyward W et al. Mixed human immunodeficiency virus (HIV) infection in an individual: demonstration of both HIV type 1 and type 2 proviral sequences by using polymerase chain reaction. $J$ Infect Dis $1988 ; 158$ : $1170-1176$.

18. Koffi K, Gershy-Damet GM, Peeters M, Soro B, Rey JL, Delaporte E. Rapid spread of HIV infections in Abidjan, Ivory Coast, 1987-1990. Eur J Clin Microbiol Infect Dis 1992; 11: 271-273.

19. Biggar RJ, Gigase PL, Melbye M et al. ELISA HTLV retrovirus antibody reactivity associated with malaria and immune complexes in healthy Africans. Lancet 1985; 2: 520-523.

20. Delaporte E, Monplaisir N, Louwagie $\mathrm{J}$ et al. Prevalence of HTLV-I and HTLV-II infection in Gabon, Africa: comparison of the serological and PCR results. Int $J$ Cancer 1991; 49: 373-376.

21. Schochetman G, Epstein JS, Zuck TF. Serodiagnosis of infection with the AIDS virus and other human retroviruses. Annu Rev Microbiol 1989; 43: 629-659.

22. Fenyö EM, Morfeldt-Månson L, Chiodi $\mathrm{F}$ et al. Distinct replicative and cytopathic characteristics of human immunodeficiency virus isolates. $J$ Virol $1988 ; 62$ : 4414-4419.

23. Heneine W, Khabbaz RF, Lal RB, Kaplan JE. Sensitive and specific polymerase chain reaction assays for diagnosis of human T-cell lymphotropic virus type I (HTLV-I) and HTLV-II infections in HTLV-I/II-seropositive individuals. J Clin Microbiol 1992; 30: 1605-1607.

24. Agius G, Biggar RJ, Alexander SS et al. Human T-lymphotropic virus type I antibody patterns: evidence of difference by age and risk group. J Infect Dis 1988; 158 : 1235-1244.

25. Ohtsuki Y, Miyoshi I, Taguchi H, Takeda I, Akagi T. Immunoelectron microscopic study on the cross-reactivity of antibodies to adult $\mathrm{T}$-cell leukemia-associated antigens in humans and monkey sera. Acta Pathol Jpn 1985; 35: 863-870.

26. Mann DL, Popovic M, Sarin $\mathbf{P}$ et al. Cell lines producing human T-cell lymphoma virus show altered HLA expression. Nature 1983; 305: 58-60.

27. Jung M, Candotti D, Huraux JM, Agut $H$. Polymerase chain reaction in human immunodeficiency virus diagnosis: principles, parameters, applications and pitfalls. Bull Inst Pasteur 1992; 90: 31-43. 
28. Simon F, Cot M-C, Lesager C et al. Differentiation between HIV-1 and HIV-2 infection by radioimmunoprecipitation and synthetic peptides in double reactive sera. AIDS 1989 ; 3: $401-402$.

29. Böttiger B, Karlsson A, Andreasson PÅ et al. Envelope crossreactivity between human immunodeficiency virus types 1 and 2 detected by different serological methods : correlation between cross-neutralization and reactivity against the main neutralizing site. $J$ Virol $1990 ; 64$ : 3492-3499.

30. Bartholomew C, Blattner W, Cleghorn F. Progression to AIDS in homosexual men co-infected with HIV and HTLV-I in Trinidad. Lancet 1987; 2: 1469. 